\title{
An Analysis of Agricultural Research Spillovers\#
}

\author{
Nathan M. Garren* and Fred C. White**
}

\section{INTRODUGTION}

Benefits resulting from publicly provided agricultural research accrue not only to producers in the state in which the research is conducted but may also spillover to producers in other states. This type of spillover from agricultural research expenditures is a form of externality because it occurs outside the market. In other words, the producers in states other than where the research is conducted do not pay for the research although they benefit from its results. Although research spillovers have been widely recognized, researchers have achieved only limited success in empirically measuring these spillovers. ${ }^{1}$ The overall objective of this paper is to empirically estimate agricultural research spillovers for major commodity groups. Production functions which account for spillovers will be estimated for cash grain, dairy, livestock, and poultry production in the United States. Then the flow of research spillovers into the Southern region will be quantified.

The organization of the paper is to first review previous specifications of the spillover variable. This review is followed by a discussion of the spillover specification used and its inclusion in a production function. The estimation procedure is then outlined. The results of the estimation process and the calculated value marginal product of research spillovers are presented. Then the magnitude of research spillovers into the Southern region will be measured for each commodity group and originating region.

\section{A REVIEW OF PRIOR SPILLOVER SPECIFICATION}

Evenson (1978) and Davis (1979) accounted for the spillover effect in aggregate production functions by including regional research expenditures which were expected to impact on production within a state. The basis for the regional divisions used in these studies was variations in soil and climate conditions. Evenson (1978) emphasized the need for similarities in geoclimatic conditions in order for the transfer of technology between states to occur.

*Assistant Professor, Extension Economics and Business, North Carolina State Univ., Raleigh, N.C.

**Professor, Department of Agricultural Economics, University of Georgia, Athens, GA.

\#This research was funded by Georgia, Hatch, and USDA/CSRS and is a contribution to IR-6. 
Norton (1980) used the same regions in estimating production functions for individual commodities. In addition, he hypothesized that "states with larger research expenditures than bordering states within the same production region are net exporters of research while those with smaller expenditures are net importers" (Norton, 1980, p. 5). The resulting spillover variable was calculated by subtracting the research expenditure of one state from each of its bordering states with higher expenditures within the same production region.

There are two possible shortcomings in Norton's specification. First, limiting spillovers to only those states within the same geoclimatic regions may prove to be too restricting in defining the source of potential spillins. This is particularly true in the case of dairy, poultry and other livestock production where soil and climate are not controlling factors. This aspect of Norton's specification seems to overlook the pervasive nature of research. Basic research is disseminated without regard to geographic boundaries. Applied research focused on a specific local problem may be adapted for more general purposes so as to meet the needs of producers in other regions. Similarities in geoclimatic conditions may facilitate the dissemination of research results, but they are not a necessary condition. Variations in soil and climate conditions across regions may affect the rate at which research results coming from other geoclimatic areas can be adopted, but they do not create absolute barriers to their use.

The second possible shortcoming in Norton's specification is his exportimport hypothesis. It seems to suggest that only those states whose expenditures are large in a relative sense will generate spillovers. Although some similarities probably exist between research projects in different states, the extreme case of complete substitutes in terms of results would not be expected. The following section on the model will include a discussion of the spillover variable which is used in the present analysis to overcome these shortcomings.

\section{MODEL SPECIFICATION}

A production function is specified to include conventional inputs and research expenditures. The use of a production function as a means of evaluating research is not new. ${ }^{2}$ Peterson and Hayami (1977) note two major advantages of this approach. First, the influence of agricultural research on agricultural output can be tested statistically. Secondly, the value marginal product of research can be computed directly since research expenditures are included as a variable within the production function. This relationship is complicated by the pervasive nature of research results. Public knowledge, which has the potential to increase productivity, cannot be withheld from individual firms. Variables which will permit the calculation of the marginal effects of spillovers will be included in the production function.

The relationship is expressed in the form of a Cobb-Douglas production function. Following Bredahl and Peterson (1976), one can abstract 
from the time dimension in the analysis. This approach assumes that the current value of research expenditures can be used as a proxy over time. The basis for such a concept is the fact that allocations among commodity groups between states have been fairly constant over time (Peterson, 1969). The production function used in this study is:

(1) $\mathrm{Q}_{h i}=\mathrm{A}_{h}{ }_{\mathrm{j}=1} \mathrm{X}^{{ }_{\mathrm{jhij}}} \mathrm{n} \pi \mathrm{k}=0 \mathrm{R}^{\alpha}{ }_{\mathrm{khik}}$

where:

$\mathrm{Q}_{\mathrm{hi}}$ is quantity of commodity h produced on the average farm in state i,

$\mathrm{X}_{\mathrm{hij}}$ is $\mathrm{jth}$ conventional input used on the average farm in state $\mathrm{i}$ in production of $h$,

$\mathrm{R}_{\text {hiO }}$ is the expenditure being made on commodity $\mathrm{h}$ in individual state i,

$R_{\text {hil }}$ is the sum of expenditures being made on commodity $h$ by other states within the same production region as state $i$,

$\mathrm{R}_{\mathrm{hi2}}$ is the sum of expenditures being made on commodity h by states in production regions tangent to the region in question,

$\mathrm{R}_{\mathrm{hi3}}$ is the sum of expenditures being made on commodity $h$ by remaining states. $R_{\mathrm{hi} 3}=\mathrm{R}_{\mathrm{hi}}-\mathrm{R}_{\mathrm{hi} 0}-\mathrm{R}_{\mathrm{hil}}-\mathrm{R}_{\mathrm{hi} 2}$ where $\mathrm{R}_{\mathrm{hi}}$ is the total research expenditure being made on that commodity within the continental United States,

$m$ is number of conventional inputs,

$\mathrm{n}$ is number of regional groupings, and

$\alpha, \beta$ are production coefficients.

The variable $\mathrm{R}_{\mathrm{hi}}$, which is simply the state's own research expenditure, is the same variable which was included in the production functions estimated by Bredahl and Peterson (1976). Its purpose is to give a means of measuring the effects on productivity accruing to a state as a result of its research expenditures. The variables $R_{\mathrm{hil}}, \mathrm{R}_{\mathrm{hi2}}$, and $\mathrm{R}_{\mathrm{hi} 3}$ account for spillovers and are based on the production regions delineated in Figure 1. The inclusion of these variables in the production function will allow for a means of calculating the marginal effects accruing to a state as a result of research expenditures made elsewhere. Under the hypotheses proposed in this study expenditures in all states may have effects, albeit differential effects, on productivity in other states.

\section{DATA}

The data were taken from three main sources. First, the source of data for conventional or non-research variables is the Census of Agriculture for the years 1969 and 1974 (U. S. Bureau of the Census, 1972 and 1977). Variable specification follows the work by Bredahl (1975) and Norton (1980). Output and conventional inputs are measured on a per farm basis 


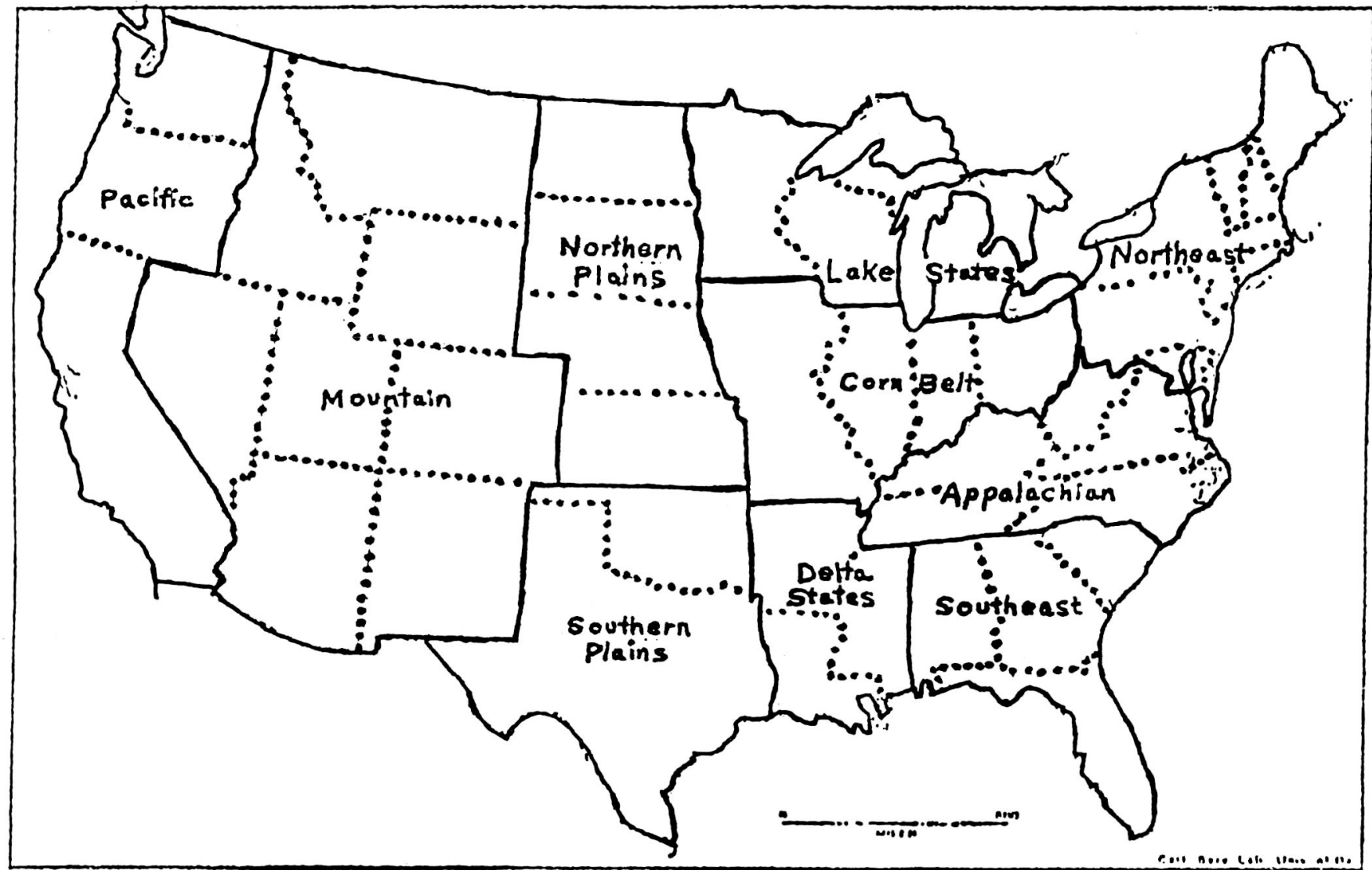

FIGURE 1. The Ten Production Regions of the United States Source: USDA, ESCS 
for average farm situations as described below. The dependent variable is output per farm measured in value terms since many different outputs are involved. Likewise, in put categories that involve many different inputs are measured in value terms. Secondly, Agricultural Prices was the source for price information used to remove from the data regional price variation and to index 1969 dollar values forward to 1974. The third source of data is the Inventory of Agricultural Research for the fiscal years 1969 and 1974 (USDA, 1970 and 1975). This source provides data for the research expenditure variables. Unlike the other variables, research expenditure will be entered on a per state and not a per farm basis. Such an approach supports the "public good" concept of the expenditure (Bredahl and Peterson, 1978). The result of a research effort has the potential of being shared equally by all farmers within a state and is not parceled out on a per farm basis. For a thorough discussion of data sources and variable specifications, see Garren (1980).

Separate production functions were estimated for cash grains, dairy. livestock, and poultry. A farm is included in one of these enterprise groups if over 50 percent of the sales of the farm is obtained from one of these commodities. Although not ideal, the division of farms into enterprise groups reduces substantially the variance in input use and output and permits comparisons across states.

\section{THE ESTIMATION PROCEDURE}

The production function, as given in equation (1), can be estimated in logarithmic form by ordinary least squares regression analysis. There exists, however, the potential problem of multicollinearity among the research variables. ${ }^{3}$ In light of this problem, an alternative approach to the estimation process will be suggested.

A traditional means of dealing with the problem of multicollinearity is to introduce prior information in the form of restrictions, thereby reducing the number of parameters to be estimated (Mittelhammer, et al., 1980). Within the context of this study, it can be assumed that a relationship exists among the coefficients associated with the research variables. Although research results have a pervasive nature, the effects of those results should vary depending on the similarities in geoclimatic conditions between the source of the research result and the state under consideration. As geoclimatic conditions become dissimilar, the adaptability of research declines. One can achieve the reduction in the number of parameters to be estimated by expressing the relationship among the research coefficients in the form of a polynomial structure.

Traditionally, the use of the polynomial structure has been applied to a temporal setting with lags. In this study, spatial application of the structure will be made. Within the context of the model, the weights will be noted as $\beta_{\mathrm{k}}$ and are assumed to be values of an unknown function, say $\mathrm{f}(\mathrm{k}), \mathrm{k}=$ $0,1, \ldots, \mathrm{n}$, where $\mathrm{n}$ is the maximum number of regional groupings $(4$ in this case). In general, even though the true function is unknown, "it can 
be approximated arbitrarily well on a closed interval by a polynomial function of a sufficiently high degree" (Judge, et al., 1980, p. 641). The distributed weights fall on a polynomial of degree $q$ which is given by

(2) $\beta_{\mathrm{k}}=\alpha+\alpha_{1} \mathrm{k}+\ldots+\alpha_{\mathrm{q}} \mathrm{k}^{\mathrm{q}}$.

With only four regional groupings, it is hypothesized that the relationship among the research variables is linear, i.e., a polynomial of degree one.

Alternative approaches exist for the estimation of the distributed weights $\beta_{\mathrm{k}}$ (see Judge, et al., 1980, pp. 641-649). It has been shown by Hill and Johnson (1976) that the constraints imposed by the model are in fact linear independent restrictions which can be imposed directly using a restricted least squares (RLS) estimator. The approach selected for this study emphasizes the restricted least squares nature of the model.

Since the specification used in this analysis is somewhat novel, more detail on its justification and contribution relative to a more traditional approach seems warranted. The model, including the four research categories, could also be estimated with ordinary least squares (OLS). These equations were estimated but are not presented here because of space limitations. An econometric technique that can be used to compare the appropriateness of OLS versus RLS is the Stein-like estimator, which, loosely speaking, averages the OLS and RLS estimates depending on the value of the appropriate F-statistic (Judge, et al., 1980, pp. 487-492). For those cases presented in this study, the RLS estimates are equivalent to Stein-like estimates, indicating that such estimates are superior to least squares.

\section{RESULTS}

\section{Regression Equations}

Production functions were estimated for four commodity groups. ${ }^{4}$ However, the relationship between research and poultry production was not statistically significant. The results for cash grain, dairy, and livestock are presented in Table 1 .

Regressions for these three production functions performed well (Table 1). The coefficients on most conventional inputs were positive and statistically significant; none were negative and statistically significant. The coefficients on conventional inputs are consistent with the estimates by Bredahl and Peterson (1976) and Norton (1980). However, in contrast to these earlier studies, the results in this study allow for an in-depth analysis of the effect of research expenditure spillovers.

Research expenditures within the state $\left(\mathrm{R}_{0}\right)$ have a positive and statistically significant effect on cash grain, dairy, and livestock production. Research expenditures within the production region but outside the state under consideration $\left(R_{1}\right)$, as well as research expenditures within adjacent production regions $\left(R_{2}\right)$ both have a positive and statistically significant effect on cash grain, dairy, and livestock production. ${ }^{5}$ However, only cash grain production is significantly affected by research expenditures within nonadjacent production regions. 
TABLE 1

Estimated Production Functions For Average Cash

Grain, Dairy, and Livestock Farms ${ }^{\mathrm{a}}$

\begin{tabular}{|c|c|c|c|}
\hline \multirow[b]{2}{*}{ Inputs } & \multicolumn{3}{|c|}{ Restricted Least Squares } \\
\hline & Cash Grain & Dairy & Livestock \\
\hline Land & $\begin{array}{r}.497 \\
(7.05)\end{array}$ & $\begin{array}{r}.111 \\
(2.62)\end{array}$ & $\begin{array}{r}.027 \\
(0.60)\end{array}$ \\
\hline Labor & $\begin{array}{r}.115 \\
(1.47)\end{array}$ & $\begin{array}{r}.251 \\
(3.11)\end{array}$ & $\begin{array}{r}.231 \\
(3.00)\end{array}$ \\
\hline Machinery & $\begin{array}{r}.178 \\
(1.15)\end{array}$ & & \\
\hline Fertilizer & $\begin{array}{r}.196 \\
(4.42)\end{array}$ & & \\
\hline Chemical & $\begin{array}{r}.103 \\
(1.39)\end{array}$ & & \\
\hline Seed & $\begin{array}{l}-.083 \\
(-.84)\end{array}$ & & \\
\hline Cows & & $\begin{array}{r}.263 \\
(2.49)\end{array}$ & \\
\hline Pasture & & $\begin{array}{r}-.007 \\
(-0.14)\end{array}$ & \\
\hline Feed & & $\begin{array}{r}.361 \\
(3.54)\end{array}$ & $\begin{array}{r}.385 \\
(5.13)\end{array}$ \\
\hline Livestock & & & $\begin{array}{r}.176 \\
(2.64)\end{array}$ \\
\hline $\mathbf{R}_{0}$ - Research expenditures within the state & $\begin{array}{r}.049 \\
(2.15)\end{array}$ & $\begin{array}{r}.058 \\
(2.55)\end{array}$ & $\begin{array}{r}.102 \\
(7.84)\end{array}$ \\
\hline $\begin{array}{l}\mathrm{R}_{1} \text { - Research expenditures within the pro- } \\
\text { duction region }\end{array}$ & $\begin{array}{r}.070 \\
(5.63)\end{array}$ & $\begin{array}{r}.049 \\
(5.69)\end{array}$ & $\begin{array}{r}.068 \\
(7.84)\end{array}$ \\
\hline $\begin{array}{l}\mathbf{R}_{2} \text { - Research expenditures within adjacent } \\
\text { production regions }\end{array}$ & $\begin{array}{r}.090 \\
(5.44)\end{array}$ & $\begin{array}{r}.040 \\
(2.58)\end{array}$ & $\begin{array}{r}.034 \\
(7.84)\end{array}$ \\
\hline $\begin{array}{l}\mathbf{R}_{3} \text { - Research expenditures within nonadja- } \\
\text { cent production regions }\end{array}$ & $\begin{array}{r}.111 \\
(3.73)\end{array}$ & $\begin{array}{r}.031 \\
(0.97)\end{array}$ & - \\
\hline $\begin{array}{l}\text { Structural shift dummy } \\
\text { variable for } 1974\end{array}$ & $\begin{array}{r}-.200 \\
(-2.71)\end{array}$ & $\begin{array}{r}.294 \\
(5.18)\end{array}$ & $\begin{array}{r}.197 \\
(3.45)\end{array}$ \\
\hline
\end{tabular}

${ }^{a}$ Student $\mathrm{t}$-values are given in parentheses.

The inability to successfully estimate the contribution of research to poultry productivity is consistent with some previous research results. Norton (1980) notes the inability of a state to capture the research benefit to the exclusion of others as a possible explanation for lack of statistical significance. If all results can be readily disseminated, then one state would not gain a comparative advantage based on a research result. The vertically integrated nature of the poultry industry contributes to rapid dis- 
semination of research results. The broiler industry approaches 90 percent vertical integration while the turkey and egg industries approach 70 percent'and 50 percent (Poultry and Egg Situation, April 1970 and June 1970). Certainly, the structured nature of the industry facilitates the dissemination and application of research results. Hence, variations in output among states would not be explained by variations in the research variables.

\section{Value Marginal Product of Research}

One means of interpreting the estimation results is to examine the value marginal product of research (VMPR) for each of the four research categories. The estimated coefficients are used to compute the "average" value marginal products of agricultural research. To obtain an average VMPR, the geometric means of the value of production and research for dairy, livestock, and cash grain for the various states are used. Estimates of the VMPR are calculated as follows:

(3) $\mathrm{VMPR}_{\mathrm{hk}}=\mathrm{b}_{\mathrm{hk}}\left(\overline{\mathrm{VP}}_{\mathrm{h}} / \overline{\mathrm{R}}_{\mathrm{hk}}\right)$

where:

$b_{h k}$ is the elasticity of production for research expenditures as measured by the RLS estimate of the coefficient of the kth research expenditure on the hth commodity,

$\overline{\mathrm{VP}}_{\mathrm{h}}$ is the geometric mean of the value of production of commodity $\mathrm{h}$, and

$\overline{\mathrm{R}}_{\mathrm{hk}}$ is the geometric mean of the research expenditure on the hth commodity by the kth regional grouping of states.

The national average VMPs are reported in Table $2 .{ }^{6}$ For each of the three commodities, the value marginal product of research within the state $\left(V_{M P R}\right)$ is the largest. For cash grain, the $\mathrm{VMPR}_{0}$ is $\$ 15.18$, while for dairy and livestock, it is $\$ 13.68$ and $\$ 61.50$, respectively. The value marginal product of the three spillin variables $\mathrm{VMPR}_{1}, \mathrm{VMPR}_{2}$, and $\mathrm{VMPR}_{3}$, become sequentially smaller. These values range from $\$ 5.88$ to $\$ 1.20$ for cash grain and from $\$ 2.03$ to $\$ 0.23$ for dairy. For livestock, $V M P R_{1}$ is $\$ 8.60$, while $\mathrm{VMPR}_{2}$ is $\$ 1.30$. When measured in terms of productivity, the dollar of research expenditures within the state generates the largest increase in productivity. The dollar expenditure by states in the same production region generates the next largest increase. The third largest increase in productivity is generated by the dollar expenditure made by the adjacent regions. Even the dollar expenditure, made by the rest of the nation, generates increases in productivity within a state for cash grains and dairy.

In order to give guidance to individual regions for allocating research funds among these commodities, value marginal products to the states conducting the research are calculated by region and presented in Table 
3. For the Southern region as a whole, the value marginal product for cash grains research is of similar magnitude to livestock research but higher than dairy research.

\section{Regional Spillover Estimates}

In this section, research spillovers into the Southern region are measured. The procedure used was to simulate production in the Southern region for the major commodity groups for selected levels of research expenditures in all regions. In the base situation, all regions had research expenditure levels equal to actual 1974 levels. Then in turn, the level of research expenditures in each region was reduced to account for one year of expenditures. ${ }^{7}$ Research spillovers from a particular region were measured as the difference between the estimated value of production in the Southern region under the base situation and under the situation in which research expenditures in the originating region had been reduced.

The magnitude of research spillovers by commodity group and originating region are reported in Table 4 . The first four regions listed in this

TABLE 2

Value Marginal Product of Research Using National Average Production and Research Expenditures

\begin{tabular}{|c|c|c|c|}
\hline & \multicolumn{3}{|c|}{ Value Marginal Product (\$) } \\
\hline & Cash Grain & Dairy & Livestock \\
\hline $\begin{array}{l}\mathbf{R}_{0} \text { - Research } \\
\text { expenditures } \\
\text { within the } \\
\text { state }\end{array}$ & 15.18 & 13.68 & 61.50 \\
\hline $\begin{array}{l}\mathrm{R}_{1} \text { - } \text { Research } \\
\text { expenditures } \\
\text { within the } \\
\text { production } \\
\text { region }\end{array}$ & 5.88 & 2.03 & 8.60 \\
\hline $\begin{array}{l}\mathrm{R}_{2} \text { - } \text { Research } \\
\text { expenditures } \\
\text { within adjacent } \\
\text { production } \\
\text { regions }\end{array}$ & 1.39 & .45 & 1.30 \\
\hline $\begin{array}{l}\mathbf{R}_{3} \text { - } \text { Research } \\
\text { expenditures } \\
\text { within non- } \\
\text { adjacent } \\
\text { production } \\
\text { regions }\end{array}$ & 1.20 & .23 & - \\
\hline
\end{tabular}


TABLE 3

Value Marginal Product of Research by Region and Commodity Group

\begin{tabular}{lrrr}
\hline \multirow{2}{*}{\multicolumn{1}{c}{ Region }} & \multicolumn{3}{c}{ Commodity Group } \\
\cline { 2 - 4 } & Cash Grains & Dairy & Livestock \\
\hline Northeast & & & 70.42 \\
Lake States & 9.48 & 17.75 & 50.03 \\
Corn Belt & 57.50 & 28.72 & 68.08 \\
Northern Plains & 62.45 & 16.79 & 81.99 \\
Appalachian & 57.66 & 19.91 & 30.62 \\
Southeast & 28.59 & 13.31 & 22.49 \\
Delta & 16.51 & 8.43 & 17.97 \\
Southern Plains & 34.45 & 3.61 & 81.57 \\
Mountain & 50.23 & 47.39 & 59.52 \\
Pacific & 26.95 & 20.73 & 50.25 \\
\hline
\end{tabular}

table-Appalachian, Southeast, Delta states, and Southern Plains-make up the Southern region as used in this analysis. Spillover estimates for these four regions are spillovers to the other three regions but still within the overall Southern region. For the remaining six regions, the spillover estimates apply to the total Southern region.

\section{TABLE 4}

Agricultural Research Spillovers into Southern Region by Commodity Group and Originating Region

\begin{tabular}{|c|c|c|c|c|}
\hline \multirow{2}{*}{$\begin{array}{c}\text { Originating } \\
\text { Region }\end{array}$} & \multicolumn{4}{|c|}{ Commodity Group } \\
\hline & Dairy & $\begin{array}{l}\text { Livestock } \\
\quad \text { (Millio }\end{array}$ & $\begin{array}{l}\text { Cash Grains } \\
\text { Dollars) }\end{array}$ & Total \\
\hline Appalachian & 2.5 & 4.5 & 24.1 & 31.0 \\
\hline Southeast & 1.4 & 3.1 & 23.1 & 27.5 \\
\hline Delta States & 3.2 & 7.4 & 20.3 & 30.8 \\
\hline Southern Plains & 0.3 & 0.6 & 9.7 & 10.6 \\
\hline Northeast & 3.1 & 0.6 & 16.3 & 20.0 \\
\hline Lake States & 2.8 & 0.0 & 28.7 & 31.5 \\
\hline Corn Belt & 3.7 & 11.8 & 57.9 & 73.4 \\
\hline Northern Plains & 1.3 & 5.9 & 53.7 & 60.9 \\
\hline Mountain & 1.5 & 4.3 & 16.6 & 22.4 \\
\hline Pacific & 1.2 & 0.0 & 18.4 & 19.6 \\
\hline Total & 20.9 & 38.1 & 268.6 & 327.7 \\
\hline
\end{tabular}


In total, $\$ 327.7$ million of agricultural output in the Southern region can be attributed to research conducted in states other than where the production occurs. Most of the research spillovers are associated with cash grains; 82.0 percent in cash grains, 11.6 percent in livestock, and 6.4 percent in dairy. The Corn Belt and the Northern Plains account for more research spillovers to the Southern region than other originating regions. In fact, these two regions account for 40 percent of all spillovers into the Southern region. This can be explained by the large level of research expenditures in these two regions and by the similarity in production of these two regions to the Southern region.

Within the Southern region itself, the Appalachian, Southeast, and Delta states all contribute about equally to spillovers. Spillovers from the Southern Plains are only one-third the level of spillovers in each of these other three regions. The Appalachian, Southeast, Delta states, and Southern Plains contribute 30 percent of all the spillovers reported in Table 3.

\section{CONCLUSIONS}

The results of this study indicate that research conducted in one state affects production in other states in the form of research spillovers. For the commodity groups considered in this analysis (cash grain, dairy, and livestock), the greatest spillover effect is on states within the same production region, and then spillover effects decline as production becomes further removed from the state conducting the research. These results have important implications for interpreting the results from other studies that ignored spillovers. By attributing all increases in productivity within a state solely to research expenditures within that state, the results from such studies would seriously bias the estimates of the value marginal product of research. It is estimated that such biased estimates would overstate the value marginal product of research from one-third to one-half its true level.

This paper has presented value marginal products of research for cash grain, dairy, and livestock production that have been corrected for spillover effects. These estimates should be useful to decision makers as they allocate research funds among these commodities. In the Southern region the value marginal product of cash grain research is similar to that of livestock research but higher than that of dairy research. Economic theory would indicate that additional research funding should be allocated to those areas with the highest value marginal product.

The approach used in this study also made it possible to estimate the magnitude of aggregate spillovers into a particular region. This concept was demonstrated by calculating spillovers into the Southern region. Annual spillover benefits into the Southern region amount to $\$ 327.7$ million, with the Corn Belt and Northern Plains providing over 40 percent of these spillovers. Over 80 percent of the spillovers into the Southern region were directly attributed to cash grains. 


\section{FOOTNOTES}

${ }^{1}$ A pioneering work related to diffusion of technology was Griliches' (1957) study of the geographic distribution of research results related to hybrid corn. Several other studies that examined the interregional diffusion of certain technologies are reviewed in Peterson and Hayami (1977).

${ }^{2}$ Griliches (1964) was one of the first to use the production function approach to estimate a marginal product of research. Evenson (1967) and Peterson (1967) also calculated a marginal product of research. The latter fitted a production function with research expenditures on poultry as a separate variable.

${ }^{3}$ One indicator of multicollinearity is the condition number which is the ratio of the largest characteristic root of the design matrix X'X to the smallest root. In this case, the roots of the cross products of the research variables are examined. The possibility of at least one near linear dependency among the research data for cash grain, dairy, livestock, and poultry is indicated by the condition numbers $5011,2958,5156$, and 1926, respectively.
${ }^{4}$ The procedure used for determining the best polynomial degree is based on the u-statistic as described in Judge, et al. (1980, pp. 645-647). In the cases of cash grain, dairy, and livestock, a polynomial of degree one was selected as best. However, similar tests indicated that the use of restricted least squares for estimating the poultry production function is inappropriate. In other words, no relationship was found between research and poultry production. ${ }^{5}$ Although the elasticity coefficients for cash grain increase from $R_{0}$ through $R_{3}$, it will be shown later that the value of marginal products decline.

${ }^{6}$ Bredahl and Peterson (1976) suggest dividing the value marginal product of research by a factor of three to take account of public extension and private research. The $\mathrm{VMPR}_{0}$ for cash grain, dairy, and livestock are then $5.06,4.56$, and 20.5 , respectively.

${ }^{7}$ Lag lengths assumed for this analysis were similar to those reported in Bredahl and Peterson (1976): five years for cash grain, six years for dairy, and seven years for livestock.

\section{REFERENCES}

1. Bredahl, M., "The Productivity and Allocation of Research at U.S. Agricultural Experiment Stations," unpublished Ph.D. Thesis, University of Minnesota, 1975

2. Bredahl, M. and W. Peterson, "The Productivity and Allocation of Research: U.S. Agricultural Experiment Stations," American Journal of Agricultural Economics, Vol. 58, No. 4, Part I, November 1976, pp. 684-692.

3. Davis, J., "Stability of the Research Production Coefficient for U.S. Agriculture," unpublished Ph.D. Thesis, University of Minnesota, 1979.

4. Evenson, R. E., "The Contribution of Agricultural Research to Production," Journal of Farm Economics, Vol. 49, December 1967, pp. 1415-1425.

5. Evenson, R. E. A Century of Productivity Change in U.S. Agriculture: An Analysis of the Role of Invention, Research, and Extension, Center Discussion Paper 296, 1978.

6. Garren, Nathan M., "The Efficient Allocation of Agricultural Research Expenditures with Externality Considerations," unpublished Ph.D. Thesis, University of Georgia, 1980.

7. Griliches, Zvi, "Hybrid Corn: An Exploration in the Economics of Technological Change," Econometrica, Vol. 25, October 1957, pp. 501-522.

8. Griliches, Z., "Research Expenditures, Education and the Aggregate Agricultural Production Function," American Economic Review, Vol. 54, No. 4, December 1964, pp. 961-974.

9. Hill, R. C., and S. R. Johnson, Almon Lags, Restricted Least Squares and the Choice of Optimal Polynomials, Working Paper, University of Georgia, Athens

10. Judge, G. G., William E. Griffiths, R. Carter Hill, and Tsoung-Chao Lee, The Theory and Practice of Econometrics, Wiley, 1980.

11. Mittelhammer, Ron C., Douglas L. Young, D. Tasanasanta, and John T. Donnelly, "Mitigating the Effects of Multicollinearity Using Exact and Stochastic Restrictions: The Case of an Aggregate Agricultural Production Function in Thailand," American Journal of Agricultural Economics, Vol. 62, 1980, pp. 199-210.

12. Norton, George, "The Productivity and Allocation of Research: U.S. Agricultural Experiment Stations, Revisited," Presented at the Symposium on Methodology for Evaluation of Agricultural Research, Minneapolis, Minnesota, 1980.

13. Peterson, W. L., "Return to Poultry Research in the United States," Journal of Farm Economics, Vol. 49, August 1967, pp. 656-669.

14. Peterson, W. L., "The Allocation of Research, Teaching, and Extension Personnel in U.S. Colleges of Agriculture," American Journal of Agricultural Economics, Vol. 51, 1969, pp. 41-56.

15. Peterson, Willis L. and Yujiro Hayami, "Technical Change in Agriculture," A Survey of Agricultural Economics Literature, Volume I, Lee R. Martin (ed.), University of Minnesota Press, Minneapolis, 1977, pp. 497-540.

16. U.S. Bureau of the Census, Census of Agriculture, 1969, U.S. Government Printing Office, Washington, D.C., 1972.

17. U.S. Bureau of the Census, Census of Agriculture, 1974, U.S. Government Printing Office, Washington, D.C., 1977.

18. U.S. Department of Agriculture, Agricultural Prices Annual Summary 1969, U.S. Government Printing Office, Washington, D.C., 1970.

19. U.S. Department of Agriculture, Agricultural Prices Annual Summary 1974, U.S. Government Printing Office, Washington, D.C., 1975.

20. U.S. Department of Agriculture, Inventory of Agricultural Research FY 1969 and 1970, U.S. Government Printing Office, Washington, D.C., 1970.

21. U.S. Department of Agriculture, Inventory of Agricultural Research FY 1974, U.S. Government Printing Office, Washington, D.C., 1975.

22. U.S. Department of Agriculture, Poultry and Egg Situation, U.S. Government Printing Office, Washington, D.C., April 1970.

23. U.S. Department of Agriculture, Poultry and Egg Situation, U.S. Government Printing Office, Washington, D.C., June 1970.

24. U.S. Department of Agriculture, That We May Eat, Yearbook of Agriculture, U.S. Government Printing Office, Washington, D.C., 1975. 